\title{
Telomeres and Age-Related Diseases
}

\author{
Hans-Jürgen Gruber, Maria Donatella Semeraro $\mathbb{D}$, Wilfried Renner *(D) and Markus Herrmann
}

check for

updates

Citation: Gruber, H.-J.; Semeraro, M.D.; Renner, W.; Herrmann, M. Telomeres and Age-Related Diseases. Biomedicines 2021, 9, 1335. https:// doi.org/10.3390/biomedicines9101335

Academic Editor: Yegor E. Yegorov

Received: 30 June 2021

Accepted: 23 September 2021

Published: 27 September 2021

Publisher's Note: MDPI stays neutral with regard to jurisdictional claims in published maps and institutional affiliations.

Copyright: (c) 2021 by the authors. Licensee MDPI, Basel, Switzerland. This article is an open access article distributed under the terms and conditions of the Creative Commons Attribution (CC BY) license (https:/ / creativecommons.org/licenses/by/ $4.0 /)$.
Clinical Institute of Medical and Chemical Laboratory Diagnostics, Medical University of Graz, 8036 Graz, Austria; hans.gruber@medunigraz.at (H.-J.G.); maria.semeraro@medunigraz.at (M.D.S.); markus.herrmann@medunigraz.at (M.H.)

* Correspondence: wilfried.renner@medunigraz.at

\begin{abstract}
Telomeres are at the non-coding ends of linear chromosomes. Through a complex 3dimensional structure, they protect the coding DNA and ensure appropriate separation of chromosomes. Aging is characterized by a progressive shortening of telomeres, which compromises their structure and function. Because of their protective function for genomic DNA, telomeres appear to play an important role in the development and progression of many age-related diseases, such as cardiovascular disease (CVD), malignancies, dementia, and osteoporosis. Despite substantial evidence that links telomere length with these conditions, the nature of these observations remains insufficiently understood. Therefore, future studies should address the question of causality. Furthermore, analytical methods should be further improved with the aim to provide informative and comparable results. This review summarize the actual knowledge of telomere biology and the possible implications of telomere dysfunction for the development and progression of age-related diseases. Furthermore, we provide an overview of analytical techniques for the measurement of telomere length and telomerase activity.
\end{abstract}

Keywords: telomere; age; disease

\section{Introduction}

Telomeres, the ends of linear chromosomes, have already been studied for over half a century, and today we possess detailed knowledge of the structural organization and physiology [1]. One key feature of telomeres is that they shorten with advancing age, which compromises their structure and function. Over the last decade, numerous studies have reported associations between telomere length and a broad range of age-related diseases including cardiovascular disease, malignancies, dementia, osteoporosis, and others [2]. However, the nature of these relationships and potential molecular mechanisms that may explain them are still insufficiently understood. A particular area of interest in this context is cancer, where genomic stability, cell differentiation, and proliferation is often compromised. Because of their protective function for genomic DNA, telomeres appear to play an important role in the development and progression of malignancies. This review summarize the actual knowledge of telomere biology and the possible implications of telomere dysfunction for the development and progression of age-related diseases.

\section{Telomeres-Structure and Functions}

Telomeres are DNA regions of variable length at the end of all chromosomes. In humans, they are composed by numerous repeats of the hexanucleotide TTAGGG and are organized in a complex 3-dimensional structure, which is essential for the protective properties of telomeres. While telomeres are double-stranded for most of their length, the very end of the leading strand is single-stranded. This single stranded overhang is the result of an incomplete lagging strand DNA synthesis, which leads to telomere shortening with every cell division, beyond telomere shortening due to accidental damage. When telomeres become critically short, cells no longer divide. In 1961, Hayflick discovered 
that the number of cell divisions in vitro is limited, known as the Hayflick limit $[3,4]$. In order to prevent inappropriate recognition of the single-stranded overhang as DNA damage and subsequent activation of the DNA damage repair (DDR) system, it is hidden inside the 3-dimensional telomere structure. Inappropriate activation of the DDR system at telomeric sites would results in non-homologous end-joining, alternative non-homologous end-joining or homologous recombination [5]. Because of the progressive shortening of telomeres due to aging, they are often referred to as a "molecular clock of aging."

Telomere function and maintenance is tightly linked to the shelterin protein complex, which consists of six individual proteins [6]. A detailed description of the shelterin proteins is given in Table 1. This nucleo-protein complex is attached to telomeres and forces doublestranded telomeric DNA to fold back, forming the so called T-loop. Furthermore, with the help of shelterin proteins, the single-stranded DNA overhang at the end of the T-Loop is hidden inside the D-loop, a short section where double-stranded telomeric DNA drifts apart (Figure 1). When telomeres become critically short, formation of the protective T-loop structure is no longer possible, which would expose the single-stranded overhang to the DDR system. To prevent the adverse consequences, like destruction of the genome a DDR signal appears, cells arrest their proliferation cycle and gradually go into senescence.

Table 1. Components of the Shelterin complex and their functions. [6-10].

\begin{tabular}{|c|c|}
\hline Shelterin Protein & Function \\
\hline Telomeric repeat binding factor 1 (TRF-1) & $\begin{array}{l}\text { TRF-1 binds the canonical } 5^{\prime} \text {-TTAGGG-3' } \\
\text { double-stranded telomeric repeats and is } \\
\text { important to determine the structure of } \\
\text { telomeric ends, as it is implicated in the } \\
\text { generation of t-loops and the regulation of } \\
\text { telomeric DNA synthesis by the } \\
\text { reverse-transcriptase telomerase. }\end{array}$ \\
\hline
\end{tabular}

TRF-2 is a paralog of TRF-1. As its paralog,

Telomeric repeat binding factor 2 (TRF-2) TRF-2 has an essential role in maintaining the conformational status of telomeres. It is implicated in telomeric ends protection and telomere length homeostasis.

TIN-2 can bridge TRF-1 to the TRF-2/RAP-1 protein complex and recruits the TPP-1/POT-1

TRF-1 interacting nuclear protein 2 (TIN-2) heterodimer to telomeric ends. In this way, TIN-2 is important for the assembly of the Shelterin complex and thereby the protection of telomeric ends.

POT-1 forms with TPP-1 a heterodimeric binding protein, which binds to the single-stranded $5^{\prime}$-TTAGGG-3' repeats. Thus,

Telomeric overhang binding protein 1 (POT-1) it is critically involved in telomere conformational changes. In this way, the interaction between POT-1 and the enzyme telomerase allows the addition of new hexanucleotides to chromosome ends.

TPP-1 forms a heterodimer with POT-1 and

TIN-2 and POT-1 interacting protein 1 (TPP-1) plays an important role in the recruitment of telomerase to telomeric ends.

RAP-1 forms a 1:1 complex with TRF-2 and is important for the structure, protection, and elongation of telomeres. As a modulator of the NF- $\mathrm{KB}$ signaling pathway, RAP-1 is also involved in the regulation of the energy metabolism. 


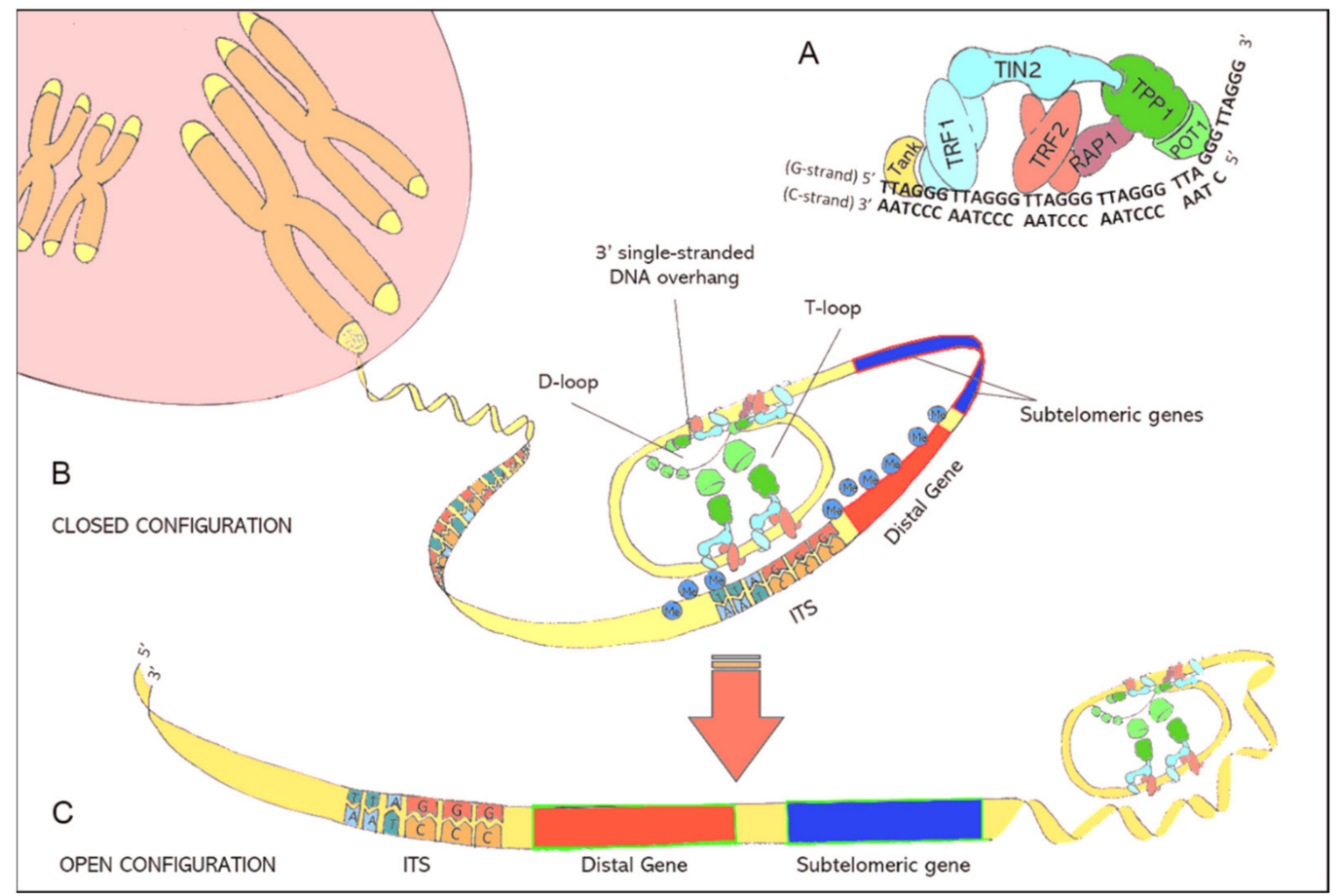

Figure 1. (A): Illustration of the shelterin nucleoprotein complex, which protects coding DNA and discriminates telomeres from other free DNA ends resulting from DNA damage. (B): Illustration of the closed chromatin configuration at telomeric ends. Due to protein-protein interactions and the specific binding of shelterins to telomeric DNA, double-stranded telomeric DNA is forced to fold back in a loop structure (T-loop) while the $3^{\prime}$ single-stranded DNA overhang is hidden inside the D-loop. The binding of shelterins to interstitial telomeric sequences (ITS) leads to the formation of interstitial telomeric loops (ITL) and establishes a closed chromatin structure that impedes the expression of subtelomeric and distal genes through telomere position effects (TPE). (C): lllustration of the open chromatin configuration at telomeric ends. Critically short telomeres can no longer maintain the compact chromatin structure. The resulting open chromatin structure facilitates the access of the translational machinery to genes that were formerly silenced by TPEs.

The compact DNA-structure of telomeres represses the expression of nearby genes through spatial hindering. This transcriptional silencing is known as telomere position effect (TPE) [11,12]. Telomeric motifs are also interspersed between genes of the coding DNA. These interstitial telomeric sequences (ITS) can interact with telomere-associated shelterin proteins, especially telomeric repeat binding factor 2 (TERF2), resulting in the formation of interstitial telomeric loops (ITL) [13]. These ITLs contribute to the complex 3-dimensional chromatin structure and permit telomeres to modify the expression of subtelomeric and distal genes. The latter is referred to as telomere position effect over long distances (TPE-OLD) [14].

\section{Telomerase}

Telomerase is a ribonucleoprotein complex that is able to elongate telomeres through the de-novo synthesis of telomeric DNA and thereby counteracting the end-replication problem [15]. It consists of the protein component telomerase reverse transcriptase (TERT), which harbors the enzyme activity, and the telomerase RNA component (TERC), also referred as human telomerase RNA (hTR). TERC serves as the template for telomere elongation. In early embryonic development, telomerase is active and ensures appropriate telomere elongation. However, within 18 weeks of gestation, the enzyme becomes inactive. In contrast, single-cell eukaryotes require a constantly active telomerase to enable continuous cell division. Telomerase silencing during embryonic life is believed to be mediated either by alternative splicing or epigenetic modifications that alter the 3-dimensional chromatin structure [16,17]. Telomerase activity in humans is primarily regulated through the expression TERT [18]. The regulation of TERC transcription is largely unknown. TERC 
belongs to the family of non-coding small Cajal body RNAs (scaRNA) and small nucleolar RNAs (snoRNA) and has its own promotor, which is in contrast to most scaRNAs and snoRNAs [19-21]. Assembling of functional telomerase depends on the structure of TERC, which can allow or prevent TERT binding [22,23]. In particular, TERT is characterized by 3 domains, the N-terminal domain, which is the telomerase RNA binding domain, the C-terminal domain, and the reverse transcriptase domain. These domains build a ring structure allowing RNA-DNA hybridisation and DNA synthesis. Through the action of additional proteins, the holoenzyme is recruited to telomeres and becomes fully activated [24-26]. Firstly, two dyskerin complexes bind to TERC followed by nucleolar protein 10 (NOP10) and NHP2. Finally, assembling of the holoenzyme is completed through association of this protein complex with WD repeat containing antisense to TP53, which regulates catalytic activity. Beyond these co-factors, several other proteins are at least transiently involved for biogenesis and assembling of the telomerase holoenzyme, including SHQ1, pontin, reptin, ATPases, the chaperones HSP90, and TriC [27-30]. Two recent publications on the structure of substrate bound telomerase using cryo electron microscopy give essentially new insights by revealing a bilobal structure [23,31]. The bilobal structure is scaffold by the RNA component and consists of the catalytic core with TERT and DNA-bound TERC as well as the H/ACA lobe. This lobe is essentially involved in the assembling and contains an H/ACA protein complex with dyskerin, NOP10, GAR1, NHP2, and telomerase Cajal body protein 1 (TCBA1).

As described above, telomeres are associated with the shelterin complex to protect the telomeric DNA from inappropriate DNA repair response. Moreover, the shelterin complex is also involved in the recruitment of telomerase to the telomeric DNA. This recruitment is cell cycle dependent and occurs in the $S$ phase [32] through binding of TERT to the shelterin protein tripeptidyl peptidase 1 [33-36]. TEN and TEL are the specific protein domains that mediated the binding of TERT to TPP-1 [37].

Taken together, the telomeric region represents a highly complex DNA-protein structure, consisting of telomeric DNA and the shelterin complex. Through interaction of the shelterin proteins with telomeric DNA, a complex 3D structure is formed that protects telomeres from inappropriate DDR activity and regulates the expression of subtelomeric and distal genes. Telomeres shorten naturally with every cell division due to the end-replication problem and accidental damage. The telomerase enzyme complex can counteract telomere shortening through de-novo synthesis of telomeric DNA.

\section{Influencing Factors of Telomere Length}

In humans, mean leukocyte telomere length (LTL) at birth is 11 kilo base pairs (kbp) and declines to less than $4 \mathrm{kbp}$ in elderly individuals [2]. However, telomere shortening is not a linear process, where a constant number of base pairs is lost with every cell division. Telomerase activity and telomere trimming events can modulate telomere length in both directions. Numerous studies have investigated non-modifiable and modifiable factors that influence telomere length. Gender, for example, is a non-modifiable factor that determines telomere length with longer telomeres being observed in females than in males [38]. This effect is mainly driven by estrogen, which mediates antioxidative effects and induces moderate telomerase activity. Psychological stress is another well-documented factor that impacts telomere homeostasis by reducing telomerase activity and increasing reactive oxidative species [39,40]. Also, nutritional factors can modulate telomere length [41-43]. In particular, a sufficient supply with micronutrients like vitamin A, D, C, E, B12, folate, and nicotinamide is positively associated with telomere length [44-48]. Minerals like magnesium, zinc, and iron, and other dietary components, such as omega-3 fatty acid, polyphenols, and curcumin, are additional modulators of telomere length. The effects of vitamins on telomere homeostasis seem to be mediated by their antioxidative properties and the prevention of DNA damage. In addition to a healthy diet, regular physical activity also contributes to the preservation of telomere length via reducing sustained oxidative stress and inflammatory mechanisms. Furthermore, exercise has been shown 
to increase telomerase activity [49-51]. Other lifestyle-related factors that potentially influence telomere length include smoking and alcohol consumption. However, to date the evidence for a significant associations between alcohol consumption and telomere length is insufficient [52]. Regarding smoking, a recent meta-analysis of 84 studies showed significantly shorter telomeres in ever smokers compared to those who never smoked [53]. Taken together, there is good evidence that a healthy and active lifestyle with sufficient sleep and a low psychologic stress level contributes to the preservation of telomeres. Physical inactivity, nutritional deficits, overweight, stress, and smoking can accelerate telomere shortening and thus promote age-related diseases.

\section{Telomeres and Age-Related Diseases}

Aging is characterized by progressive telomere shortening due to cell division and telomere erosion. Individuals of the same age with the shortest telomeres have compared to those with the longest telomeres a higher hazard ratio for all-cause mortality [54,55]. Furthermore, telomere length is also related to the incidence, progression, and diseasespecific mortality of individual age-related diseases, such as CVD, type 2 diabetes, cancer, and Alzheimer's disease [56]. These associations are believed to be the result of the agerelated telomere shortening, which contributes to genomic instability and modulates gene expression through TPE, TPE-OLD, and DDR activation [57]. Critically short telomeres cannot loop back to form genomic ITS, which silence nearby genes. As a result, the expression of these genes is increased [58-60]. Interestingly, one of the genes that is regulated via TPE-OLD and ITL is TERT, which encodes the telomere elongating enzyme telomerase [61]. The activation of TERT expression in the context of short telomeres is considered as a protective mechanism that prevents rapid telomere shortening. It is believed that the physiologic stimulation of telomerase activity through physical activity, healthy nutrition, and other modifiable lifestyle factors can reduce the risk for age-related diseases and promote healthy aging [51]. This concept is supported by experimental studies in mice showing that constitutive TERT expression delays aging and extends life span [62-64]. However, it is also well established that the constitutive expression of TERT is strongly associated with carcinogenesis and TERT inhibition in cancer cells reduces tumour growth due to the induction of cell death [65-69]. This suggests that only the physiologic stimulation of TERT may have beneficial effects [62-64]. However, this assertion is discussed controversial as activation of telomerase as therapeutic target may have beneficial effects in telomere-shortening-associated conditions [70].

Another mechanism involved in the shortening of telomeres is the clonal hematopoiesis of undetermined potential (CHIP) [71]. Naturally occurring somatic mutations in hematopoietic stem cells accumulate with advancing age and can induce the clonal expansion of mutated leucocytes. The prevalence of CHIP is very low in subjects younger than 40 years, but increases up to $10 \%$ and $20 \%$ by the age of 70 and 80 years, respectively [72]. Individuals with CHIP have significantly shorter telomeres, and moreover, a whole-genome analysis study including 11,262 participants revealed that CHIP showed the strongest association with the TERT gene, in particular a germline deletion in intron 3 [73]. Clinically, CHIP carriers have a higher risk for haematological malignancy and adverse cardiovascular events [74-76].

\section{Cardiovascular Diseases (CVD)}

In developed countries, CVD is one of the most frequent age-related diseases and represents the leading cause of death. The prevalence of cardiovascular diseases (CVD) and the frequency of CVD-related complications increases with advancing age. Expression of TERT and the presence of telomerase activity in cardiomyocytes and blood vessels have nurtured the idea that telomeres might be of particular importance for cardiovascular aging [77-79]. Over the last two decades, numerous human and animal studies have investigated the role of telomeres and telomerase in CVD with inconsistent results. Most of them measured telomere length in leucocytes (LTL) as a surrogate marker for telomere 
length in solid tissues, which are not easily accessible. Several prospective cohort studies have found an elevated risk of CVD, myocardial infarction, heart failure, and stroke in individuals with a low LTL and a high telomere attrition rate [80-85]. Amongst 800 men and women who participated in the prospective, population-based Bruneck study, LTL was an independent predictor of myocardial infarction and stroke [86]. CVD risk differed between individuals with the longest and shortest LTL by a factor of 2.72. However, with only 88 CVD events, the number of end-points was rather low. Consistent with the Bruneck study, in over 1500 Scottish people with and without CVD, individuals in the lowest and the middle tertile of LTL had a $40-50 \%$ higher risk for incident CVD during follow-up [80]. Another study of patients with and without early myocardial infarction ( $<50$ years) found that LTL of patients was equivalent to controls that were 11.3 years older [87]. An interesting study by Benetos et al. showed that the association of short telomere length and atherosclerotic cardiovascular disease is based on a higher telomere attrition rate in early life [88]. This observation alludes to additional telomere-related effects in CVD that go beyond normal age-related telomere shortening. In addition to coronary atherosclerosis and myocardial ischemia, the risk of ischemic, atherothrombotic, and haemorrhagic stroke also seems to be associated with telomere length [89-93]. Also, Martin-Ruiz et al. found that telomere length is associated with post-stroke mortality [94]. However, not all studies corroborate an association of LTL with CVD and stroke [95-99]. To address the inconsistencies of existing studies, Haycock et al. performed a meta-analysis of 24 studies with over 43,000 participants and 8400 CVD patients [100]. Individuals with the shortest LTL had a 54\% higher CVD risk than those with the longest LTL, and when considering only prospective studies relative risk of CVD was still $40 \%$ higher in individuals with short telomeres. Despite their significant results, meta-analyses should be interpreted with caution as the studies included varied substantially in study design and patient characteristics. This is particularly important when considering that CVD is a highly multifactorial entity that is associated with multiple risk factors, such as age, gender, obesity, physical inactivity, genetic predisposition, and others, and involves several pathomechanisms including inflammation, oxidative stress, and dyslipidemia [100,101].

Telomere length and telomerase activity show huge interindividual variability, and as a result, most human cohort studies found only a weak correlation between LTL and age. Considering the many factors that affect telomere length, this observation is not surprising. As discussed earlier, LTL has been reported to be influenced by many lifestyle factors including sleep, physical activity, psychological stress, and nutritional factors [48,102-104]. Furthermore, oxidative stress and chronic inflammation are key factors that impact telomere length [47]. Besides many lifestyle and environmental factors, telomere length and telomerase activity are strongly determined by the inherited genetic background, with heritability estimates ranging from $34 \%$ to $82 \%$ [105]. Interestingly, the maternal influence on telomere length seems to be stronger than the paternal influence. This genetic basis can be used for Mendelian randomization (MR) studies to evaluate the potential causal relationship between telomere length and age-relates diseases. In an analogy to randomized clinical trials, MR creates study groups stratified by genotypes, which are independent of confounding factors and are inherited at random. MR studies are more robust to confounding factors or reverse causation than observational studies [106]. In a large MR study including more than 261.000 participants, Kuo and coworkers could show a modest causal association between LTL and lower CVD and cancer risk. However, no causal association of LTL with other age-related health outcomes was found [107]. Furthermore, GWAS studies have identified seven SNPs that are responsible for interindividual variations in LTL. The presence of these alleles seems to be related with an increased CVD risk. In a meta-analysis by Codd et al. one standard deviation reduction in LTL was associated with a $21 \%$ higher CVD risk [108].

Chronic inflammation and oxidative stress are critical factors that promote atherosclerosis. In addition, they accelerate telomere shortening and cause premature cellular senescence in endothelial cells, vascular smooth muscle cells (VSMC) and blood leukocytes [109]. 
The severity of CVD seems to be correlated with the reduction of telomere length in VSMCs of human atherosclerotic plaques. Also, VSMCs of atherosclerotic plaques are characterized by oxidative DNA damage and the expression of typical senescence markers, such as senescence-associated galactosidase, cyclin-dependent kinase inhibitors p16 and p21, decreased expression of cyclin D and cyclin E, and hypophosphorylation of the retinoblastoma protein [110]. Senescent VSMCs harbor a limited proliferative capacity and an increased amount of matrix-degrading enzymes, which stimulate the thinning of fibrous caps and plaque rupture [111]. In patients with acute coronary syndrome, a low LTL is linked to the presence of highly unstable atherosclerotic plaques and an increased proinflammatory activity [112]. Accelerated telomere shortening also goes along with functional exhaustion and impaired proliferative capacity of bone marrow-derived endothelial progenitor cells. These cells are of critical importance for the re-endothelialization process of damaged blood vessels. As a result, re-endothelialization after vascular injury and stent implantation is delayed in individuals with short telomeres [113]. Another piece of evidence that underpins the role of telomeres in CVD is the observation that statins, which are commonly used to treat hyperlipidaemia, modify TERT expression and telomerase activity in the vascular wall and in cells of the immune system [114]. Furthermore, in an experimental mouse model, long telomeres were protective against age-dependent cardiac disease caused by NOTCH1 haploinsufficiency [115].

Beyond telomeres, telomerase is also discussed to be involved in cardiovascular diseases due to its noncanonical and nonnuclear functions. Telomerase is also present in mitochondria, thereby improving membrane potential, reducing mitochondrial reactive oxygen species (ROS) production. These effects counteract the induction of apoptosis by protecting mitochondrial DNA [116-118]. In preclinical models, telomerase has also been shown to be involved in autophagy through inhibition of mammalian target of rapamycin complex 1 (mTORC1), especially under calorie restriction conditions, thereby improving diastolic dysfunction $[119,120]$.

In summary, there is substantial evidence that links short telomeres and accelerated telomere shortening to CVD. However, at present it is still unclear whether telomeres are causally involved in the development and progression of CVD or if this association simply represents an epiphenomenon.

\section{Type 2 Diabetes (T2DM)}

T2DM, a common risk factors for CVD, is a multifactorial disease that is mainly driven by obesity and physical inactivity. Several studies have shown that individuals with short telomeres have a higher risk of T2DM, a faster disease progression and more diabetic complications, such as retinopathy, nephropathy, neuropathy, and peripheral vascular disease [121-129]. Also, a recent meta-analysis by D'Mello et al. supports a significant association between telomere length and T2DM [130]. Short telomeres in T2DM seem to go along with epigenetic modifications. In Chinese diabetics, short telomeres have been found to be associated hyper-methylation of LINE-1, a surrogate marker for global DNA methylation [131]. Furthermore, in TERT knockout mice with premature telomere shortening, the proliferative senescence of adipose progenitor cells contributes to ageing, obesity, and diabetes [132]. An autopsy study by Tamura et al. revealed shorter telomeres in the beta-cells of T2DM patients than in non-diabetic individuals [133]. While the studies discussed before support an association between telomeres and T2DM, others do not. In a recent general population study with 3921 participants, Menke et al. found no association of LTL with diabetes status, diabetes duration, or diabetes control [134]. Likewise, in the Finnish Diabetes Prevention Study, Hovatte et al. found no association between short telomeres and the development of T2DM during 8.5 years of follow up [135]. A MR study by You et al. also failed to show an association between telomere length and T2DM risk [136]. However, a direct comparison of different studies is limited by the substantial heterogeneity of their study design and the age, ethnicity, sex, and health status of the participants. 
In summary, there is some evidence indicating an association of accelerated telomere shortening with T2DM. However, existing studies are inconsistent and mainly of observational nature. Therefore, the role of telomere function in T2DM remains unclear and more research is needed to understand if there is a mechanistic link.

\section{Cancer}

Similar to CVD and T2DM, the incidence of cancer also increases with age. Considering the protective role of telomeres for genomic DNA, numerous studies have investigated if telomere length is related to cancer risk or prognosis [2,137]. Existing results suggest a dual role of telomeres in neoplastic diseases. Short telomeres seem to increase the risk for incident cancer. On the other hand, with the malignant transformation it is believed that critically short telomeres contribute to cancer progression and the reactivation of telomerase [138]. In contrast to somatic cells, up to $90 \%$ of human tumor tissue is characterized by telomerase activity [18]. This telomerase reactivation is a tumor escape mechanism that confers immortalization to affected cells and promotes tumor invasion and metastasis.

There is solid evidence that the telomeres from cells of cancerous lesion are shorter than in healthy tissue from the same organ [139-142]. Furthermore, telomeres from peritumoral tissue are shorter than from more distant areas [143]. It has also been reported that in breast and prostate cancer tissue, short telomeres are related to an advanced disease state at diagnosis, faster disease progression, and poorer survival $[139,144]$. Most studies ignored the fact that telomere length varies between chromosomes and cells. However, the variability of telomere length seems to be a risk factor for cancer-related death. The practical limitations of telomere length measurement in tumor tissue lead researchers to analyze LTL in most large human studies. In population-based, prospective studies, a low LTL at baseline was associated with a substantially higher risk for incident tumors and tumor-specific mortality $[145,146]$. Serial LTL measurements, such as in the normative Aging Study, showed that subjects with incident cancer had a markedly higher telomere shortening rate than subjects without [138]. However, there are also studies that did not find significant associations between LTL and cancer risk [147], and others reported a higher LTL in cancer patients than in cancer-free subjects [148]. These inconsistent results are further supported by two meta-analyses of retrospective [149] and prospective studies [150]. While the pooled analyses of retrospective studies showed an inverse relationship between LTL and cancer risk, this was not the case when considering only prospective studies.

Under physiologic circumstances, the natural process of progressive telomere shortening with ongoing cell division and aging ends with critically short telomeres, which induce replicative senescence $[151,152]$. In this situation, chromosomal ends are no longer protected and therefore recognized by the DDR machinery. Finally, telomere crisis facilitates autophagy and ultimately leads to cell death. Tumor cells can escape this mechanisms by the reactivation of telomerase [153-155]. The reactivation of telomerase leads to telomere elongation and thus prevents telomere crisis with subsequent cell death. Various mechanisms for the reactivation of telomerase in tumor cells have been proposed. For example, mutations in the TERT promotor region can increase TERT transcription [156]. Such mutations have been described in various tumour types of tissues with low of self-renewal rates, e.g., melanoma, hepatocellular carcinoma, glioblastoma, and urothelial cancer [157-159]. The wildtype promotor of TERT is silenced by methylated histon H3, whereas the mutated allele is associated with non-silencing H3 variants, thus enabling TERT expression [160]. Moreover, transcription is driven by recruitment of the transcription factor GA binding protein transcription factor subunit alpha (GABPA) and subunit beta (GABPB) to the mutated promotor, leading to an increased transcription of the mutated TERT allele in cancer cells [161]. However, the majority of tumors harbor increased telomerase activity without activating mutations. Several other mechanisms, such as gene amplification of TERT, where the number of copies of the TERT gene is increased due to errors in the DNA replication and repair machinery, have been described. For example, TERT gene amplification has been found in ovarian and lung cancer [162]. Chromosome rearrangements can also upregulate 
TERT expression, such as in neuroblastoma $[163,164]$. Another intriguing mechanism that can activate TERT expression has been described in hepatocellular carcinoma, where a hepatitis $B$ infection can result in integration of the virus genome near the TERT promotor [165]. In this scenario, TERT expression is increased through viral enhancer elements [165]. Tumour cells can overcome telomere shortening also by alternative telomere lengthening via homologous recombination mechanisms resulting in heterogeneous telomeres. This type of telomere length preservation has been described for neuroendocrine tumours and sarcomas [166]. TPEs, where critically short telomeres induce the expression of genes near the telomeric region may also mediate telomere maintenance in cancer cells [167].

The cancer associated activation of telomerase is of particular interest as it may represent a potential target for novel therapeutic strategies in cancer patients. Several therapeutic approaches aim to antagonize the continuous activation of telomerase in cancer cells [168]. An advantage of telomerase-targeting therapies is the fact that proliferating cancer cells have shorter telomeres compared to normal somatic cells, which should make them more sensitive to anti-telomerase therapeutics [169]. One of the most promising candidates for telomerase-targeted cancer therapy may be the first-in-class telomerase inhibitor Imetelstat, which is currently tested in a phase 3 clinical trial (ImpactMF; NCT04576156) with an estimated enrollment of 320 patients with refractory myelofibrosis (MF). Results of the trial are expected for May 2024.

In summary, telomere biology in cancer is highly complex, and the role of telomeres in the development and perpetuation of cancerous lesions is still subject to intensive research. So far, it seems that short telomeres increase the risk for cancer formation, whereas telomerase reactivation and preserved telomeres are important for tumour growth and survival.

\section{Alzheimer's Disease (AD)}

In the aging populations of developed countries, dementia and AD affect a rapidly rising number of individuals. Despite a better understanding of the underlying pathological mechanisms, effective therapies for this devastating disease are still lacking. Therefore, a lot of research is focused on risk prediction, early diagnosis, and the identification of modifiable risk factors. Age-related telomere shortening has been proposed to contribute to neuronal dysfunction and cognitive decline in elderly individuals. In this context, previous studies reported shorter LTL in AD patients than in non-demented controls [170]. According to Panossian et al., the inverse relationship between LTL and AD risk is primarily driven by $\mathrm{T}$ lymphocytes, but not B lymphocytes or monocytes [171]. Furthermore, telomere length in T cells is inversely correlated with serum levels of TNF- $\alpha$, with the proportion of CD8+ T cells lacking expression of the CD28 co-stimulatory molecule, and with apoptosis. In a recent meta-analysis, Forero et al. confirmed a significant difference in LTL between AD patients and controls [172]. However, most of the studies considered in this metaanalysis were of cross-sectional nature and included a rather small number of AD patients. Until today, only a few large prospective observation studies have been published Honig et al. analysed LTL in 1,978 elderly individuals from the prospective Washington HeightsInwood Community Aging Project, and found significantly shorter LTL in participants with prevalent or incident dementia [173]. In 1,961 elderly participants of the Rotterdam study, LTL showed a U-shaped association with AD and all-cause dementia [174]. While the increase of $\mathrm{AD}$ risk in individuals with short telomeres is in line with previous studies, the link between over-elongated telomeres and AD risk is not yet understood and needs further clarification. Experimental studies that may shed some light into potential mechanisms are largely lacking. In one of the few existing studies, neurons of TERT knockout mice showed shorter telomeres, an increased production of oxidative species and an increase in cellular oxidative damage in response to tau [175]. A higher AD risk in individuals with long telomeres is supported by the observation that over-elongated telomeres in human embryonic stem cells become fragile and accumulate DNA damage [176]. According to 
this study, telomere homeostasis is not only regulated by telomerase activity, but also by telomere trimming events.

Tedone et al. reported that LTL is not only associated with AD risk, but also with disease progression [177]. Late onset $\mathrm{AD}$ patients with slow disease progression had shorter telomeres than those with fast disease progression or healthy elderly controls. Although there is substantial evidence for an association between LTL and dementia, an analysis of telomere length in matched pairs of peripheral blood leucocytes and cerebellum samples from AD patients and unaffected controls questions a causal relationship [178]. While LTL and telomere length in the cerebellum of AD patients were correlated, the latter did not differ between $\mathrm{AD}$ patients and controls.

Taken together, existing studies provide robust evidence for an association between LTL and AD risk. However, the nature of this relationship is largely unclear. It remains to be elucidated whether low LTL in AD patients represents a cumulative marker of various $\mathrm{AD}$ risk factors or if short telomeres are mechanistically involved in the development and progression of dementia.

\section{Osteoporosis}

Like many other tissues, also bone cells exhibit an age-related decline in telomere length. In addition, premature aging syndromes, such as Werner syndrome and congenital dyskeratosis, are characterized by telomere dysfunction and osteoporosis. These observations have led to the hypothesis that the age-related shortening of telomeres does also contribute to the development and progression of osteoporosis, a highly prevalent condition amongst elderly individuals [179]. A large population-based study in 2150 women between 18 and 79 years supports this idea by showing a significant correlation between LTL and bone mineral density (BMD) at the spine and forearm [180]. Furthermore, risk of clinical osteoporosis was lower in women with longer telomeres. The difference in LTL between women with and without osteoporosis was equivalent to five years of telomeric aging. Also in elderly men (71-86 years), LTL correlated with bone loss at the distal forearm [181]. In vitro experiments with cultured mesenchymal stroma cells showed a reduced proliferative and osteogenic capacity in osteoporotic patients [182]. Additional support for a causal link between osteoporosis and short telomeres comes from an in vivo study in telomerase deficient mice [183]. The accelerated telomere shortening in these animals was associated with bone loss due to dysfunctional osteoblasts and osteoclasts. In another mouse study of accelerated aging, Wang et al. showed an impairment of osteoblast differentiation due to proliferation-independent telomere dysfunction [184].

The studies discussed before are contrasted by several other studies that did not find significant relationships between LTL, BMD and osteoporosis [185-187]. Two large-scale observational cohort studies in community-dwelling women failed to show significant associations of BMD, bone loss, and prevalent and incident fractures with LTL $[186,187]$. Also, a comparison of telomere length in human osteoblasts and peripheral blood leucocytes from young, elderly, and osteoporotic women did not support the concept of accelerated telomere shortening and premature cellular aging in osteoporotic patients [188]. In a recent review, Fragkiadaki et al. stated that despite a number of promising studies there is still a lot of inconsistencies in the available literature [179]. Therefore, without further observational and experimental studies the impact of age-related telomere shortening on bone aging and osteoporosis cannot be established.

\section{Analytical Aspects}

The methods for TL measurements vary widely as traditional techniques have been refined and new techniques have emerged [189]. Beyond the terminal restriction fragment (TRF) analysis by Southern blot as the gold standard, quantitative fluorescence in situ hybridization with flow cytomerty (qFISH) and PCR applications such as qPCR, STELA (Single Telomere Length Assay) and TESLA (Telomere Shortest Length Assay) are used for TL analyses [190-193]. qPCR is the most commonly used method for telomere length 
analysis, because it is cheap and can easily be performed in a large number of samples. As the result is the ratio of relative TL to a single copy gene, this method gives no information about the shortest telomeres or differences between chromosomes. In contrast, qFISH analysis in combination with TRF determines absolute telomere length and provides information on the shortest telomeres. This is of particular interest as it is hypothesised that not average telomere length, but the shortest telomeres drive chromosomal instability and reduce cell viability [194]. This method seems to have the potential to provide more diseaserelated information on alterations of telomere length. However, the method is laborious and therefore hard to use for large sample analysis. For analysis of telomerase activity the telomeric repeat amplification protocol (TRAP) is most commonly used. It consists in a two-step PCR including telomerase mediated primer amplification and subsequent qPCR analysis of the amplification products. To analyze TA in single cells a droplet digital TRAP (ddTRAP) assay was developed by Ludlow et al. [195], which provides more sensitivity and better throughput [196]. However, TA assays are hard to standardize and not practicable for clinical studies. Most clinical studies are also limited by the fact that the source for telomere analyses are whole blood samples, and therefore, TL and TA of blood leucocytes is determined [197-199]. Leucocytes represent a heterogeneous cell population with a highly variable composition, depending on environmental and lifestyle factors like nutrition, physical activity, and psychological stress. To date, it is not clear if leucocytes are a suitable surrogate to investigate telomere dynamics in other solid organs. A recent analysis of 6391 samples from the Genotype-Tissue Expression (GTEx) project showed that LTL correlates with the telomere length of some, but not all, somatic tissue types [200].

\section{Conclusions}

There is a large body of evidence that supports significant associations between telomere length and age-related diseases, such as CVD, T2DM, cancer, dementia, and osteoporosis. However, existing studies are heterogeneous, and a substantial number of studies did not find significant relationships. Furthermore, most clinical studies are limited by the measurement of average telomere length in peripheral blood leucocytes, which may not necessarily reflect the situation in other solid organ tissues, such as myocardium, blood vessels, brain, or bone. Mechanistic studies that confirm a mechanistic involvement of short telomeres in common age-related diseases are largely lacking. Last but not least, available methods for the measurement are poorly standardized and provide different information, which strongly limits the comparability between studies. Future research projects should focus on the question of causality. Also, methods should be selected on the basis of their analytical capabilities and harmonized wherever possible.

Author Contributions: Conceptualization, investigation, writing-review and editing, H.-J.G., M.D.S., W.R., and M.H.; visualization, M.D.S. All authors have read and agreed to the published version of the manuscript.

Funding: This research received no external funding.

Institutional Review Board Statement: Not applicable.

Informed Consent Statement: Not applicable.

Conflicts of Interest: The authors declare no conflict of interest.

\section{References}

1. Shay, J.W.; Wright, W.E. Telomeres and telomerase: Three decades of progress. Nat. Rev. Genet. 2019, 20, 299-309. [CrossRef] [PubMed]

2. Herrmann, M.; Pusceddu, I.; Marz, W.; Herrmann, W. Telomere biology and age-related diseases. Clin. Chem. Lab. Med. 2018, 56, 1210-1222. [CrossRef] [PubMed]

3. Hayflick, L. The Limited in Vitro Lifetime of Human Diploid Cell Strains. Exp. Cell Res. 1965, 37, 614-636. [CrossRef]

4. Hayflick, L.; Moorhead, P.S. The serial cultivation of human diploid cell strains. Exp. Cell Res. 1961, 25, 585-621. [CrossRef]

5. Lazzerini-Denchi, E.; Sfeir, A. Stop pulling my strings-what telomeres taught us about the DNA damage response. Nat. Rev. Mol. Cell Biol. 2016, 17, 364-378. [CrossRef] 
6. de Lange, T. Shelterin: The protein complex that shapes and safeguards human telomeres. Genes Dev. 2005, 19, 2100-2110. [CrossRef]

7. Van Steensel, B.; de Lange, T. Control of telomere length by the human telomeric protein TRF1. Nature 1997, 385, 740-743. [CrossRef]

8. Lei, M.; Podell, E.R.; Cech, T.R. Structure of human POT1 bound to telomeric single-stranded DNA provides a model for chromosome end-protection. Nat. Struct. Mol. Biol. 2004, 11, 1223-1229. [CrossRef]

9. Palm, W.; de Lange, T. How shelterin protects mammalian telomeres. Annu. Rev. Genet. 2008, 42, 301-334. [CrossRef]

10. Teo, H.; Ghosh, S.; Luesch, H.; Ghosh, A.; Wong, E.T.; Malik, N.; Orth, A.; de Jesus, P.; Perry, A.S.; Oliver, J.D.; et al. Telomereindependent Rap1 is an IKK adaptor and regulates NF-kappaB-dependent gene expression. Nat. Cell Biol. 2010, $12,758-767$. [CrossRef]

11. Robin, J.D.; Ludlow, A.T.; Batten, K.; Magdinier, F.; Stadler, G.; Wagner, K.R.; Shay, J.W.; Wright, W.E. Telomere position effect: Regulation of gene expression with progressive telomere shortening over long distances. Genes Dev. 2014, 28, $2464-2476$. [CrossRef] [PubMed]

12. Baur, J.A.; Zou, Y.; Shay, J.W.; Wright, W.E. Telomere position effect in human cells. Science 2001, 292, 2075-2077. [CrossRef] [PubMed]

13. Greider, C.W. Regulating telomere length from the inside out: The replication fork model. Genes Dev. 2016, 30, 1483-1491. [CrossRef] [PubMed]

14. Rowley, M.J.; Corces, V.G. The three-dimensional genome: Principles and roles of long-distance interactions. Curr. Opin. Cell Biol. 2016, 40, 8-14. [CrossRef]

15. Wang, Y.; Susac, L.; Feigon, J. Structural Biology of Telomerase. Cold Spring Harb. Perspect. Biol. 2019, 11, a032383. [CrossRef]

16. Blasco, M.A. The epigenetic regulation of mammalian telomeres. Nat. Rev. Genet. 2007, 8, 299-309. [CrossRef]

17. Wong, M.S.; Wright, W.E.; Shay, J.W. Alternative splicing regulation of telomerase: A new paradigm? Trends Genet. 2014, 30, 430-438. [CrossRef]

18. Roake, C.M.; Artandi, S.E. Regulation of human telomerase in homeostasis and disease. Nat. Rev. Mol. Cell Biol. 2020, 21, 384-397. [CrossRef]

19. Bachand, F.; Kukolj, G.; Autexier, C. Expression of hTERT and hTR in cis reconstitutes and active human telomerase ribonucleoprotein. RNA 2000, 6, 778-784. [CrossRef] [PubMed]

20. Feng, J.; Funk, W.D.; Wang, S.S.; Weinrich, S.L.; Avilion, A.A.; Chiu, C.P.; Adams, R.R.; Chang, E.; Allsopp, R.C.; Yu, J.; et al. The RNA component of human telomerase. Science 1995, 269, 1236-1241. [CrossRef] [PubMed]

21. Weinrich, S.L.; Pruzan, R.; Ma, L.; Ouellette, M.; Tesmer, V.M.; Holt, S.E.; Bodnar, A.G.; Lichtsteiner, S.; Kim, N.W.; Trager, J.B.; et al. Reconstitution of human telomerase with the template RNA component hTR and the catalytic protein subunit hTRT. Nat. Genet. 1997, 17, 498-502. [CrossRef]

22. Jiang, J.; Chan, H.; Cash, D.D.; Miracco, E.J.; Ogorzalek Loo, R.R.; Upton, H.E.; Cascio, D.; O’Brien Johnson, R.; Collins, K.; Loo, J.A.; et al. Structure of Tetrahymena telomerase reveals previously unknown subunits, functions, and interactions. Science 2015, 350, aab4070. [CrossRef]

23. Jiang, J.; Wang, Y.; Susac, L.; Chan, H.; Basu, R.; Zhou, Z.H.; Feigon, J. Structure of Telomerase with Telomeric DNA. Cell 2018, 173, 1179-1190.e1113. [CrossRef] [PubMed]

24. Cohen, S.B.; Graham, M.E.; Lovrecz, G.O.; Bache, N.; Robinson, P.J.; Reddel, R.R. Protein composition of catalytically active human telomerase from immortal cells. Science 2007, 315, 1850-1853. [CrossRef] [PubMed]

25. Egan, E.D.; Collins, K. Biogenesis of telomerase ribonucleoproteins. RNA 2012, 18, 1747-1759. [CrossRef]

26. Fu, D.; Collins, K. Purification of human telomerase complexes identifies factors involved in telomerase biogenesis and telomere length regulation. Mol. Cell 2007, 28, 773-785. [CrossRef] [PubMed]

27. Freund, A.; Zhong, F.L.; Venteicher, A.S.; Meng, Z.; Veenstra, T.D.; Frydman, J.; Artandi, S.E. Proteostatic control of telomerase function through TRiC-mediated folding of TCAB1. Cell 2014, 159, 1389-1403. [CrossRef] [PubMed]

28. Grozdanov, P.N.; Roy, S.; Kittur, N.; Meier, U.T. SHQ1 is required prior to NAF1 for assembly of H/ACA small nucleolar and telomerase RNPs. RNA 2009, 15, 1188-1197. [CrossRef]

29. Toogun, O.A.; Dezwaan, D.C.; Freeman, B.C. The hsp90 molecular chaperone modulates multiple telomerase activities. Mol. Cell Biol. 2008, 28, 457-467. [CrossRef]

30. Wang, C.; Meier, U.T. Architecture and assembly of mammalian H/ACA small nucleolar and telomerase ribonucleoproteins. EMBO J. 2004, 23, 1857-1867. [CrossRef]

31. Nguyen, T.H.D.; Tam, J.; Wu, R.A.; Greber, B.J.; Toso, D.; Nogales, E.; Collins, K. Cryo-EM structure of substrate-bound human telomerase holoenzyme. Nature 2018, 557, 190-195. [CrossRef]

32. Schmidt, J.C.; Zaug, A.J.; Cech, T.R. Live Cell Imaging Reveals the Dynamics of Telomerase Recruitment to Telomeres. Cell 2016, 166, 1188-1197.e1189. [CrossRef]

33. Abreu, E.; Aritonovska, E.; Reichenbach, P.; Cristofari, G.; Culp, B.; Terns, R.M.; Lingner, J.; Terns, M.P. TIN2-tethered TPP1 recruits human telomerase to telomeres in vivo. Mol. Cell Biol. 2010, 30, 2971-2982. [CrossRef] [PubMed]

34. Baumann, P.; Cech, T.R. Pot1, the putative telomere end-binding protein in fission yeast and humans. Science 2001, 292, 1171-1175. [CrossRef] [PubMed] 
35. Frank, A.K.; Tran, D.C.; Qu, R.W.; Stohr, B.A.; Segal, D.J.; Xu, L. The Shelterin TIN2 Subunit Mediates Recruitment of Telomerase to Telomeres. PLoS Genet. 2015, 11, e1005410. [CrossRef] [PubMed]

36. Takai, K.K.; Kibe, T.; Donigian, J.R.; Frescas, D.; de Lange, T. Telomere protection by TPP1/POT1 requires tethering to TIN2. Mol. Cell 2011, 44, 647-659. [CrossRef]

37. Nandakumar, J.; Bell, C.F.; Weidenfeld, I.; Zaug, A.J.; Leinwand, L.A.; Cech, T.R. The TEL patch of telomere protein TPP1 mediates telomerase recruitment and processivity. Nature 2012, 492, 285-289. [CrossRef]

38. Lulkiewicz, M.; Bajsert, J.; Kopczynski, P.; Barczak, W.; Rubis, B. Telomere length: How the length makes a difference. Mol. Biol. Rep. 2020, 47, 7181-7188. [CrossRef]

39. Epel, E.S.; Blackburn, E.H.; Lin, J.; Dhabhar, F.S.; Adler, N.E.; Morrow, J.D.; Cawthon, R.M. Accelerated telomere shortening in response to life stress. Proc. Natl. Acad. Sci. USA 2004, 101, 17312-17315. [CrossRef]

40. Ornish, D.; Lin, J.; Daubenmier, J.; Weidner, G.; Epel, E.; Kemp, C.; Magbanua, M.J.; Marlin, R.; Yglecias, L.; Carroll, P.R.; et al. Increased telomerase activity and comprehensive lifestyle changes: A pilot study. Lancet Oncol. 2008, 9, 1048-1057. [CrossRef]

41. Freitas-Simoes, T.M.; Ros, E.; Sala-Vila, A. Nutrients, foods, dietary patterns and telomere length: Update of epidemiological studies and randomized trials. Metabolism 2016, 65, 406-415. [CrossRef] [PubMed]

42. Paul, L. Diet, nutrition and telomere length. J. Nutr. Biochem. 2011, 22, 895-901. [CrossRef] [PubMed]

43. Pusceddu, I.; Farrell, C.J.; Di Pierro, A.M.; Jani, E.; Herrmann, W.; Herrmann, M. The role of telomeres and vitamin D in cellular aging and age-related diseases. Clin. Chem. Lab. Med. 2015, 53, 1661-1678. [CrossRef] [PubMed]

44. Borras, M.; Panizo, S.; Sarro, F.; Valdivielso, J.M.; Fernandez, E. Assessment of the potential role of active vitamin D treatment in telomere length: A case-control study in hemodialysis patients. Clin. Ther. 2012, 34, 849-856. [CrossRef] [PubMed]

45. Pusceddu, I.; Herrmann, M.; Kirsch, S.H.; Werner, C.; Hubner, U.; Bodis, M.; Laufs, U.; Wagenpfeil, S.; Geisel, J.; Herrmann, W. Prospective study of telomere length and LINE-1 methylation in peripheral blood cells: The role of B vitamins supplementation. Eur. J. Nutr. 2016, 55, 1863-1873. [CrossRef] [PubMed]

46. Pusceddu, I.; Herrmann, M.; Kirsch, S.H.; Werner, C.; Hubner, U.; Bodis, M.; Laufs, U.; Widmann, T.; Wagenpfeil, S.; Geisel, J.; et al. One-carbon metabolites and telomere length in a prospective and randomized study of B- and/or D-vitamin supplementation. Eur. J. Nutr. 2017, 56, 1887-1898. [CrossRef]

47. Pusceddu, I.; Herrmann, W.; Kleber, M.E.; Scharnagl, H.; Hoffmann, M.M.; Winklhofer-Roob, B.M.; Marz, W.; Herrmann, M. Subclinical inflammation, telomere shortening, homocysteine, vitamin B6, and mortality: The Ludwigshafen Risk and Cardiovascular Health Study. Eur. J. Nutr. 2020, 59, 1399-1411. [CrossRef]

48. Pusceddu, I.; Herrmann, W.; Kleber, M.E.; Scharnagl, H.; Marz, W.; Herrmann, M. Telomere length, vitamin B12 and mortality in persons undergoing coronary angiography: The Ludwigshafen risk and cardiovascular health study. Aging 2019, 11, 7083-7097. [CrossRef]

49. Arsenis, N.C.; You, T.; Ogawa, E.F.; Tinsley, G.M.; Zuo, L. Physical activity and telomere length: Impact of aging and potential mechanisms of action. Oncotarget 2017, 8, 45008-45019. [CrossRef]

50. Balan, E.; Decottignies, A.; Deldicque, L. Physical Activity and Nutrition: Two Promising Strategies for Telomere Maintenance? Nutrients 2018, 10, 1942. [CrossRef]

51. Semeraro, M.D.; Smith, C.; Kaiser, M.; Levinger, I.; Duque, G.; Gruber, H.J.; Herrmann, M. Physical activity, a modulator of aging through effects on telomere biology. Aging 2020, 12, 13803-13823. [CrossRef]

52. Maugeri, A.; Barchitta, M.; Magnano San Lio, R.; La Rosa, M.C.; La Mastra, C.; Favara, G.; Ferlito, M.; Giunta, G.; Panella, M.; Cianci, A.; et al. The Effect of Alcohol on Telomere Length: A Systematic Review of Epidemiological Evidence and a Pilot Study during Pregnancy. Int. J. Environ. Res. Public Health 2021, 18, 5038. [CrossRef] [PubMed]

53. Astuti, Y.; Wardhana, A.; Watkins, J.; Wulaningsih, W.; Network, P.R. Cigarette smoking and telomere length: A systematic review of 84 studies and meta-analysis. Environ. Res. 2017, 158, 480-489. [CrossRef]

54. Boccardi, M.; Boccardi, V. Psychological Wellbeing and Healthy Aging: Focus on Telomeres. Geriatrics 2019, 4, 25. [CrossRef]

55. Goglin, S.E.; Farzaneh-Far, R.; Epel, E.S.; Lin, J.; Blackburn, E.H.; Whooley, M.A. Correction: Change in Leukocyte Telomere Length Predicts Mortality in Patients with Stable Coronary Heart Disease from the Heart and Soul Study. PLoS ONE 2016, 11, e0168868. [CrossRef]

56. Pusceddu, I.; Kleber, M.; Delgado, G.; Herrmann, W.; Marz, W.; Herrmann, M. Telomere length and mortality in the Ludwigshafen Risk and Cardiovascular Health study. PLoS ONE 2018, 13, e0198373. [CrossRef]

57. Shay, J.W. Telomeres and aging. Curr. Opin. Cell Biol. 2018, 52, 1-7. [CrossRef]

58. Lou, Z.; Wei, J.; Riethman, H.; Baur, J.A.; Voglauer, R.; Shay, J.W.; Wright, W.E. Telomere length regulates ISG15 expression in human cells. Aging 2009, 1, 608-621. [CrossRef]

59. Robin, J.D.; Ludlow, A.T.; Batten, K.; Gaillard, M.C.; Stadler, G.; Magdinier, F.; Wright, W.E.; Shay, J.W. SORBS2 transcription is activated by telomere position effect-over long distance upon telomere shortening in muscle cells from patients with facioscapulohumeral dystrophy. Genome Res. 2015, 25, 1781-1790. [CrossRef] [PubMed]

60. Stadler, G.; Rahimov, F.; King, O.D.; Chen, J.C.; Robin, J.D.; Wagner, K.R.; Shay, J.W.; Emerson, C.P., Jr.; Wright, W.E. Telomere position effect regulates DUX4 in human facioscapulohumeral muscular dystrophy. Nat. Struct. Mol. Biol. 2013, $20,671-678$. [CrossRef] [PubMed] 
61. Kim, W.; Ludlow, A.T.; Min, J.; Robin, J.D.; Stadler, G.; Mender, I.; Lai, T.P.; Zhang, N.; Wright, W.E.; Shay, J.W. Regulation of the Human Telomerase Gene TERT by Telomere Position Effect-Over Long Distances (TPE-OLD): Implications for Aging and Cancer. PLoS Biol. 2016, 14, e2000016. [CrossRef]

62. Bernardes de Jesus, B.; Blasco, M.A. Aging by telomere loss can be reversed. Cell Stem Cell 2011, 8, 3-4. [CrossRef]

63. Jaskelioff, M.; Muller, F.L.; Paik, J.H.; Thomas, E.; Jiang, S.; Adams, A.C.; Sahin, E.; Kost-Alimova, M.; Protopopov, A.; Cadinanos, J.; et al. Telomerase reactivation reverses tissue degeneration in aged telomerase-deficient mice. Nature 2011, 469, 102-106. [CrossRef]

64. Tomas-Loba, A.; Flores, I.; Fernandez-Marcos, P.J.; Cayuela, M.L.; Maraver, A.; Tejera, A.; Borras, C.; Matheu, A.; Klatt, P.; Flores, J.M.; et al. Telomerase reverse transcriptase delays aging in cancer-resistant mice. Cell 2008, 135, 609-622. [CrossRef]

65. Hahn, W.C.; Stewart, S.A.; Brooks, M.W.; York, S.G.; Eaton, E.; Kurachi, A.; Beijersbergen, R.L.; Knoll, J.H.; Meyerson, M.; Weinberg, R.A. Inhibition of telomerase limits the growth of human cancer cells. Nat. Med. 1999, 5, 1164-1170. [CrossRef]

66. Herbert, B.; Pitts, A.E.; Baker, S.I.; Hamilton, S.E.; Wright, W.E.; Shay, J.W.; Corey, D.R. Inhibition of human telomerase in immortal human cells leads to progressive telomere shortening and cell death. Proc. Natl. Acad. Sci. USA 1999, 96, 14276-14281. [CrossRef] [PubMed]

67. Jafri, M.A.; Ansari, S.A.; Alqahtani, M.H.; Shay, J.W. Roles of telomeres and telomerase in cancer, and advances in telomerasetargeted therapies. Genome Med. 2016, 8, 69. [CrossRef] [PubMed]

68. Shay, J.W.; Bacchetti, S. A survey of telomerase activity in human cancer. Eur. J. Cancer 1997, 33, 787-791. [CrossRef]

69. Zhang, X.; Mar, V.; Zhou, W.; Harrington, L.; Robinson, M.O. Telomere shortening and apoptosis in telomerase-inhibited human tumor cells. Genes Dev. 1999, 13, 2388-2399. [CrossRef] [PubMed]

70. Yegorov, Y.E.; Poznyak, A.V.; Nikiforov, N.G.; Starodubova, A.V.; Orekhov, A.N. Role of Telomeres Shortening in Atherogenesis: An Overview. Cells 2021, 10, 395. [CrossRef] [PubMed]

71. Aviv, A.; Levy, D. Hemothelium, Clonal Hematopoiesis of Indeterminate Potential, and Atherosclerosis. Circulation 2019, 139, 7-9. [CrossRef]

72. Xie, M.; Lu, C.; Wang, J.; McLellan, M.D.; Johnson, K.J.; Wendl, M.C.; McMichael, J.F.; Schmidt, H.K.; Yellapantula, V.; Miller, C.A.; et al. Age-related mutations associated with clonal hematopoietic expansion and malignancies. Nat. Med. 2014, 20, 1472-1478. [CrossRef] [PubMed]

73. Zink, F.; Stacey, S.N.; Norddahl, G.L.; Frigge, M.L.; Magnusson, O.T.; Jonsdottir, I.; Thorgeirsson, T.E.; Sigurdsson, A.; Gudjonsson, S.A.; Gudmundsson, J.; et al. Clonal hematopoiesis, with and without candidate driver mutations, is common in the elderly. Blood 2017, 130, 742-752. [CrossRef] [PubMed]

74. Genovese, G.; Kahler, A.K.; Handsaker, R.E.; Lindberg, J.; Rose, S.A.; Bakhoum, S.F.; Chambert, K.; Mick, E.; Neale, B.M.; Fromer, M.; et al. Clonal hematopoiesis and blood-cancer risk inferred from blood DNA sequence. N. Engl. J. Med. 2014, 371, $2477-2487$. [CrossRef]

75. Jaiswal, S.; Fontanillas, P.; Flannick, J.; Manning, A.; Grauman, P.V.; Mar, B.G.; Lindsley, R.C.; Mermel, C.H.; Burtt, N.; Chavez, A.; et al. Age-related clonal hematopoiesis associated with adverse outcomes. N. Engl. J. Med. 2014, 371, 2488-2498. [CrossRef]

76. Jaiswal, S.; Libby, P. Clonal haematopoiesis: Connecting ageing and inflammation in cardiovascular disease. Nat. Rev. Cardiol 2020, 17, 137-144. [CrossRef]

77. Chang, A.C.Y.; Chang, A.C.H.; Kirillova, A.; Sasagawa, K.; Su, W.; Weber, G.; Lin, J.; Termglinchan, V.; Karakikes, I.; Seeger, T.; et al. Telomere shortening is a hallmark of genetic cardiomyopathies. Proc. Natl. Acad. Sci. USA 2018, 115, 9276-9281. [CrossRef] [PubMed]

78. Frati, G.; Versaci, F.; Sciarretta, S. A novel signalling mechanism regulating telomere length in cardiomyocytes. Cardiovasc. Res. 2021, 117, 13-14. [CrossRef] [PubMed]

79. Morgan, R.G.; Donato, A.J.; Walker, A.E. Telomere uncapping and vascular aging. Am. J. Physiol.-Heart Circ. Physiol. 2018, 315, H1-H5. [CrossRef]

80. Brouilette, S.W.; Moore, J.S.; McMahon, A.D.; Thompson, J.R.; Ford, I.; Shepherd, J.; Packard, C.J.; Samani, N.J.; West of Scotland Coronary Prevention Study Group. Telomere length, risk of coronary heart disease, and statin treatment in the West of Scotland Primary Prevention Study: A nested case-control study. Lancet 2007, 369, 107-114. [CrossRef]

81. Cawthon, R.M.; Smith, K.R.; O’Brien, E.; Sivatchenko, A.; Kerber, R.A. Association between telomere length in blood and mortality in people aged 60 years or older. Lancet 2003, 361, 393-395. [CrossRef]

82. Ogami, M.; Ikura, Y.; Ohsawa, M.; Matsuo, T.; Kayo, S.; Yoshimi, N.; Hai, E.; Shirai, N.; Ehara, S.; Komatsu, R.; et al. Telomere shortening in human coronary artery diseases. Arterioscler. Thromb. Vasc. Biol. 2004, 24, 546-550. [CrossRef]

83. Ridker, P.M.; Everett, B.M.; Thuren, T.; MacFadyen, J.G.; Chang, W.H.; Ballantyne, C.; Fonseca, F.; Nicolau, J.; Koenig, W.; Anker, S.D.; et al. Antiinflammatory Therapy with Canakinumab for Atherosclerotic Disease. N. Engl. J. Med. 2017, 377, 1119-1131. [CrossRef]

84. Sawhney, V.; Campbell, N.G.; Brouilette, S.W.; Coppen, S.R.; Harbo, M.; Baker, V.; Ikebe, C.; Shintani, Y.; Hunter, R.J.; Dhinoja, M.; et al. Telomere shortening and telomerase activity in ischaemic cardiomyopathy patients—Potential markers of ventricular arrhythmia. Int. J. Cardiol. 2016, 207, 157-163. [CrossRef]

85. Sharifi-Sanjani, M.; Oyster, N.M.; Tichy, E.D.; Bedi, K.C., Jr.; Harel, O.; Margulies, K.B.; Mourkioti, F. Cardiomyocyte-Specific Telomere Shortening is a Distinct Signature of Heart Failure in Humans. J. Am. Heart Assoc. 2017, 6, e005086. [CrossRef] [PubMed] 
86. Willeit, P.; Willeit, J.; Brandstatter, A.; Ehrlenbach, S.; Mayr, A.; Gasperi, A.; Weger, S.; Oberhollenzer, F.; Reindl, M.; Kronenberg, F.; et al. Cellular aging reflected by leukocyte telomere length predicts advanced atherosclerosis and cardiovascular disease risk. Arterioscler. Thromb. Vasc. Biol. 2010, 30, 1649-1656. [CrossRef] [PubMed]

87. Brouilette, S.; Singh, R.K.; Thompson, J.R.; Goodall, A.H.; Samani, N.J. White cell telomere length and risk of premature myocardial infarction. Arterioscler. Thromb. Vasc. Biol. 2003, 23, 842-846. [CrossRef] [PubMed]

88. Benetos, A.; Toupance, S.; Gautier, S.; Labat, C.; Kimura, M.; Rossi, P.M.; Settembre, N.; Hubert, J.; Frimat, L.; Bertrand, B.; et al. Short Leukocyte Telomere Length Precedes Clinical Expression of Atherosclerosis: The Blood-and-Muscle Model. Circ. Res. 2018, 122, 616-623. [CrossRef] [PubMed]

89. Gao, D.; Zhang, R.; Ji, G.; Li, C.; Guo, D.; Jin, T.; Chen, M. Relative Telomere Length and Stroke Risk in a Chinese Han Population. J. Mol. Neurosci. 2018, 66, 475-481. [CrossRef]

90. Allende, M.; Molina, E.; Gonzalez-Porras, J.R.; Toledo, E.; Lecumberri, R.; Hermida, J. Short Leukocyte Telomere Length Is Associated With Cardioembolic Stroke Risk in Patients With Atrial Fibrillation. Stroke 2016, 47, 863-865. [CrossRef]

91. Ding, H.; Chen, C.; Shaffer, J.R.; Liu, L.; Xu, Y.; Wang, X.; Hui, R.; Wang, D.W. Telomere length and risk of stroke in Chinese. Stroke 2012, 43, 658-663. [CrossRef]

92. Jiang, X.; Dong, M.; Cheng, J.; Huang, S.; He, Y.; Ma, K.; Tang, B.; Guo, Y. Decreased leukocyte telomere length (LTL) is associated with stroke but unlikely to be causative. PLOS ONE 2013, 8, e68254. [CrossRef]

93. Zhang, W.; Chen, Y.; Wang, Y.; Liu, P.; Zhang, M.; Zhang, C.; Hu, F.B.; Hui, R. Short telomere length in blood leucocytes contributes to the presence of atherothrombotic stroke and haemorrhagic stroke and risk of post-stroke death. Clin. Sci. 2013, 125, 27-36. [CrossRef]

94. Martin-Ruiz, C.; Dickinson, H.O.; Keys, B.; Rowan, E.; Kenny, R.A.; Von Zglinicki, T. Telomere length predicts poststroke mortality, dementia, and cognitive decline. Ann. Neurol. 2006, 60, 174-180. [CrossRef]

95. Fyhrquist, F.; Silventoinen, K.; Saijonmaa, O.; Kontula, K.; Devereux, R.B.; de Faire, U.; Os, I.; Dahlof, B. Telomere length and cardiovascular risk in hypertensive patients with left ventricular hypertrophy: The LIFE study. J. Hum. Hypertens. 2011, 25, 711-718. [CrossRef]

96. Njajou, O.T.; Hsueh, W.C.; Blackburn, E.H.; Newman, A.B.; Wu, S.H.; Li, R.; Simonsick, E.M.; Harris, T.M.; Cummings, S.R.; Cawthon, R.M.; et al. Association between telomere length, specific causes of death, and years of healthy life in health, aging, and body composition, a population-based cohort study. J. Gerontol. A Biol. Sci. Med. Sci. 2009, 64, 860-864. [CrossRef]

97. Schurks, M.; Prescott, J.; Dushkes, R.; De Vivo, I.; Rexrode, K.M. Telomere length and ischaemic stroke in women: A nested case-control study. Eur. J. Neurol. 2013, 20, 1068-1074. [CrossRef] [PubMed]

98. Weischer, M.; Bojesen, S.E.; Cawthon, R.M.; Freiberg, J.J.; Tybjaerg-Hansen, A.; Nordestgaard, B.G. Short telomere length, myocardial infarction, ischemic heart disease, and early death. Arterioscler. Thromb. Vasc. Biol. 2012, 32, 822-829. [CrossRef] [PubMed]

99. Zee, R.Y.; Castonguay, A.J.; Barton, N.S.; Ridker, P.M. Relative leukocyte telomere length and risk of incident ischemic stroke in men: A prospective, nested case-control approach. Rejuvenation Res. 2010, 13, 411-414. [CrossRef]

100. Haycock, P.C.; Heydon, E.E.; Kaptoge, S.; Butterworth, A.S.; Thompson, A.; Willeit, P. Leucocyte telomere length and risk of cardiovascular disease: Systematic review and meta-analysis. BMJ 2014, 349, g4227. [CrossRef] [PubMed]

101. Hoffmann, J.; Richardson, G.; Haendeler, J.; Altschmied, J.; Andres, V.; Spyridopoulos, I. Telomerase as a Therapeutic Target in Cardiovascular Disease. Arterioscler. Thromb. Vasc. Biol. 2021, 41, 1047-1061. [CrossRef] [PubMed]

102. Werner, C.; Furster, T.; Widmann, T.; Poss, J.; Roggia, C.; Hanhoun, M.; Scharhag, J.; Buchner, N.; Meyer, T.; Kindermann, W.; et al. Physical exercise prevents cellular senescence in circulating leukocytes and in the vessel wall. Circulation 2009, 120, $2438-2447$. [CrossRef] [PubMed]

103. Werner, C.; Hanhoun, M.; Widmann, T.; Kazakov, A.; Semenov, A.; Poss, J.; Bauersachs, J.; Thum, T.; Pfreundschuh, M.; Muller, P.; et al. Effects of physical exercise on myocardial telomere-regulating proteins, survival pathways, and apoptosis. J. Am. Coll. Cardiol. 2008, 52, 470-482. [CrossRef]

104. Werner, C.M.; Hecksteden, A.; Morsch, A.; Zundler, J.; Wegmann, M.; Kratzsch, J.; Thiery, J.; Hohl, M.; Bittenbring, J.T.; Neumann, F.; et al. Differential effects of endurance, interval, and resistance training on telomerase activity and telomere length in a randomized, controlled study. Eur. Heart J. 2019, 40, 34-46. [CrossRef]

105. Broer, L.; Codd, V.; Nyholt, D.R.; Deelen, J.; Mangino, M.; Willemsen, G.; Albrecht, E.; Amin, N.; Beekman, M.; de Geus, E.J.; et al. Meta-analysis of telomere length in 19,713 subjects reveals high heritability, stronger maternal inheritance and a paternal age effect. Eur. J. Hum. Genet. 2013, 21, 1163-1168. [CrossRef]

106. Davey Smith, G.; Hemani, G. Mendelian randomization: Genetic anchors for causal inference in epidemiological studies. Hum. Mol. Genet. 2014, 23, R89-R98. [CrossRef]

107. Kuo, C.L.; Pilling, L.C.; Kuchel, G.A.; Ferrucci, L.; Melzer, D. Telomere length and aging-related outcomes in humans: A Mendelian randomization study in 261,000 older participants. Aging Cell 2019, 18, e13017. [CrossRef]

108. Codd, V.; Nelson, C.P.; Albrecht, E.; Mangino, M.; Deelen, J.; Buxton, J.L.; Hottenga, J.J.; Fischer, K.; Esko, T.; Surakka, I.; et al. Identification of seven loci affecting mean telomere length and their association with disease. Nat. Genet. 2013, 45, 422-427. [CrossRef] [PubMed]

109. Yeh, J.K.; Wang, C.Y. Telomeres and Telomerase in Cardiovascular Diseases. Genes 2016, 7, 58. [CrossRef] [PubMed] 
110. Matthews, C.; Gorenne, I.; Scott, S.; Figg, N.; Kirkpatrick, P.; Ritchie, A.; Goddard, M.; Bennett, M. Vascular smooth muscle cells undergo telomere-based senescence in human atherosclerosis: Effects of telomerase and oxidative stress. Circ. Res. 2006, 99, 156-164. [CrossRef]

111. Gorenne, I.; Kavurma, M.; Scott, S.; Bennett, M. Vascular smooth muscle cell senescence in atherosclerosis. Cardiovasc. Res. 2006, 72, 9-17. [CrossRef]

112. Calvert, P.A.; Liew, T.V.; Gorenne, I.; Clarke, M.; Costopoulos, C.; Obaid, D.R.; O'Sullivan, M.; Shapiro, L.M.; McNab, D.C.; Densem, C.G.; et al. Leukocyte telomere length is associated with high-risk plaques on virtual histology intravascular ultrasound and increased proinflammatory activity. Arterioscler. Thromb. Vasc. Biol. 2011, 31, 2157-2164. [CrossRef]

113. Armstrong, E.J.; Xing, L.; Zhang, J.; Zheng, Y.; Shunk, K.A.; Yeh, R.W.; Farzaneh-Far, R.; Yu, B.; Jang, I.K. Association between leukocyte telomere length and drug-eluting stent strut coverage by optical coherence tomography. J. Am. Coll. Cardiol. 2012, 59, 2218-2219. [CrossRef]

114. Boccardi, V.; Barbieri, M.; Rizzo, M.R.; Marfella, R.; Esposito, A.; Marano, L.; Paolisso, G. A new pleiotropic effect of statins in elderly: Modulation of telomerase activity. FASEB J. 2013, 27, 3879-3885. [CrossRef] [PubMed]

115. Theodoris, C.V.; Mourkioti, F.; Huang, Y.; Ranade, S.S.; Liu, L.; Blau, H.M.; Srivastava, D. Long telomeres protect against age-dependent cardiac disease caused by NOTCH1 haploinsufficiency. J. Clin. Investig. 2017, 127, 1683-1688. [CrossRef] [PubMed]

116. Ahmed, S.; Passos, J.F.; Birket, M.J.; Beckmann, T.; Brings, S.; Peters, H.; Birch-Machin, M.A.; von Zglinicki, T.; Saretzki, G. Telomerase does not counteract telomere shortening but protects mitochondrial function under oxidative stress. J. Cell Sci. 2008, 121, 1046-1053. [CrossRef] [PubMed]

117. Haendeler, J.; Drose, S.; Buchner, N.; Jakob, S.; Altschmied, J.; Goy, C.; Spyridopoulos, I.; Zeiher, A.M.; Brandt, U.; Dimmeler, S. Mitochondrial telomerase reverse transcriptase binds to and protects mitochondrial DNA and function from damage. Arterioscler. Thromb. Vasc. Biol. 2009, 29, 929-935. [CrossRef] [PubMed]

118. Sharma, N.K.; Reyes, A.; Green, P.; Caron, M.J.; Bonini, M.G.; Gordon, D.M.; Holt, I.J.; Santos, J.H. Human telomerase acts as a hTR-independent reverse transcriptase in mitochondria. Nucleic Acids Res. 2012, 40, 712-725. [CrossRef]

119. Ali, M.; Devkota, S.; Roh, J.I.; Lee, J.; Lee, H.W. Telomerase reverse transcriptase induces basal and amino acid starvation-induced autophagy through mTORC1. Biochem. Biophys. Res. Commun. 2016, 478, 1198-1204. [CrossRef]

120. Makino, N.; Oyama, J.; Maeda, T.; Koyanagi, M.; Higuchi, Y.; Tsuchida, K. Calorie restriction increases telomerase activity, enhances autophagy, and improves diastolic dysfunction in diabetic rat hearts. Mol. Cell Biochem. 2015, 403, 1-11. [CrossRef] [PubMed]

121. Adaikalakoteswari, A.; Balasubramanyam, M.; Mohan, V. Telomere shortening occurs in Asian Indian Type 2 diabetic patients. Diabet. Med. 2005, 22, 1151-1156. [CrossRef] [PubMed]

122. Adaikalakoteswari, A.; Balasubramanyam, M.; Ravikumar, R.; Deepa, R.; Mohan, V. Association of telomere shortening with impaired glucose tolerance and diabetic macroangiopathy. Atherosclerosis 2007, 195, 83-89. [CrossRef] [PubMed]

123. Salpea, K.D.; Talmud, P.J.; Cooper, J.A.; Maubaret, C.G.; Stephens, J.W.; Abelak, K.; Humphries, S.E. Association of telomere length with type 2 diabetes, oxidative stress and UCP2 gene variation. Atherosclerosis 2010, 209, 42-50. [CrossRef] [PubMed]

124. Shen, Q.; Zhao, X.; Yu, L.; Zhang, Z.; Zhou, D.; Kan, M.; Zhang, D.; Cao, L.; Xing, Q.; Yang, Y.; et al. Association of leukocyte telomere length with type 2 diabetes in mainland Chinese populations. J. Clin. Endocrinol. Metab. 2012, 97, 1371-1374. [CrossRef] [PubMed]

125. Tentolouris, N.; Nzietchueng, R.; Cattan, V.; Poitevin, G.; Lacolley, P.; Papazafiropoulou, A.; Perrea, D.; Katsilambros, N.; Benetos, A. White blood cells telomere length is shorter in males with type 2 diabetes and microalbuminuria. Diabetes Care 2007, 30, 2909-2915. [CrossRef] [PubMed]

126. Testa, R.; Olivieri, F.; Sirolla, C.; Spazzafumo, L.; Rippo, M.R.; Marra, M.; Bonfigli, A.R.; Ceriello, A.; Antonicelli, R.; Franceschi, C.; et al. Leukocyte telomere length is associated with complications of type 2 diabetes mellitus. Diabet. Med. 2011, 28, 1388-1394. [CrossRef] [PubMed]

127. Willeit, P.; Raschenberger, J.; Heydon, E.E.; Tsimikas, S.; Haun, M.; Mayr, A.; Weger, S.; Witztum, J.L.; Butterworth, A.S.; Willeit, J.; et al. Leucocyte telomere length and risk of type 2 diabetes mellitus: New prospective cohort study and literature-based meta-analysis. PLoS ONE 2014, 9, e112483. [CrossRef]

128. Xiao, F.; Zheng, X.; Cui, M.; Shi, G.; Chen, X.; Li, R.; Song, Z.; Rudolph, K.L.; Chen, B.; Ju, Z. Telomere dysfunction-related serological markers are associated with type 2 diabetes. Diabetes Care 2011, 34, 2273-2278. [CrossRef]

129. Zhao, J.; Zhu, Y.; Lin, J.; Matsuguchi, T.; Blackburn, E.; Zhang, Y.; Cole, S.A.; Best, L.G.; Lee, E.T.; Howard, B.V. Short leukocyte telomere length predicts risk of diabetes in american indians: The strong heart family study. Diabetes 2014, 63, 354-362. [CrossRef]

130. D'Mello, M.J.; Ross, S.A.; Briel, M.; Anand, S.S.; Gerstein, H.; Pare, G. Association between shortened leukocyte telomere length and cardiometabolic outcomes: Systematic review and meta-analysis. Circ. Cardiovasc. Genet. 2015, 8, 82-90. [CrossRef]

131. Wu, Y.; Cui, W.; Zhang, D.; Wu, W.; Yang, Z. The shortening of leukocyte telomere length relates to DNA hypermethylation of LINE-1 in type 2 diabetes mellitus. Oncotarget 2017, 8, 73964-73973. [CrossRef]

132. Gao, Z.; Daquinag, A.C.; Fussell, C.; Zhao, Z.; Dai, Y.; Rivera, A.; Snyder, B.E.; Eckel-Mahan, K.L.; Kolonin, M.G. Age-associated telomere attrition in adipocyte progenitors predisposes to metabolic disease. Nat. Metab. 2020, 2, 1482-1497. [CrossRef] 
133. Tamura, Y.; Izumiyama-Shimomura, N.; Kimbara, Y.; Nakamura, K.; Ishikawa, N.; Aida, J.; Chiba, Y.; Mori, S.; Arai, T.; Aizawa, T.; et al. Beta-cell telomere attrition in diabetes: Inverse correlation between $\mathrm{HbA1c}$ and telomere length. J. Clin. Endocrinol. Metab. 2014, 99, 2771-2777. [CrossRef] [PubMed]

134. Menke, A.; Casagrande, S.; Cowie, C.C. Leukocyte telomere length and diabetes status, duration, and control: The 1999-2002 National Health and Nutrition Examination Survey. BMC Endocr. Disord. 2015, 15, 52. [CrossRef]

135. Hovatta, I.; de Mello, V.D.; Kananen, L.; Lindstrom, J.; Eriksson, J.G.; Ilanne-Parikka, P.; Keinanen-Kiukaanniemi, S.; Peltonen, M.; Tuomilehto, J.; Uusitupa, M. Leukocyte telomere length in the Finnish Diabetes Prevention Study. PLoS ONE 2012, 7, e34948. [CrossRef]

136. You, N.C.; Chen, B.H.; Song, Y.; Lu, X.; Chen, Y.; Manson, J.E.; Kang, M.; Howard, B.V.; Margolis, K.L.; Curb, J.D.; et al. A prospective study of leukocyte telomere length and risk of type 2 diabetes in postmenopausal women. Diabetes 2012, 61, 2998-3004. [CrossRef]

137. Hou, L.; Zhang, X.; Gawron, A.J.; Liu, J. Surrogate tissue telomere length and cancer risk: Shorter or longer? Cancer Lett. 2012, 319, 130-135. [CrossRef]

138. Hou, L.; Joyce, B.T.; Gao, T.; Liu, L.; Zheng, Y.; Penedo, F.J.; Liu, S.; Zhang, W.; Bergan, R.; Dai, Q.; et al. Blood Telomere Length Attrition and Cancer Development in the Normative Aging Study Cohort. EBioMedicine 2015, 2, 591-596. [CrossRef]

139. Fordyce, C.A.; Heaphy, C.M.; Bisoffi, M.; Wyaco, J.L.; Joste, N.E.; Mangalik, A.; Baumgartner, K.B.; Baumgartner, R.N.; Hunt, W.C.; Griffith, J.K. Telomere content correlates with stage and prognosis in breast cancer. Breast Cancer Res. Treat. 2006, 99, 193-202. [CrossRef]

140. Heaphy, C.M.; Fleet, T.M.; Treat, E.G.; Lee, S.J.; Smith, A.Y.; Davis, M.S.; Griffith, J.K.; Fischer, E.G.; Bisoffi, M. Organ-wide telomeric status in diseased and disease-free prostatic tissues. Prostate 2010, 70, 1471-1479. [CrossRef] [PubMed]

141. Nakamura, K.; Furugori, E.; Esaki, Y.; Arai, T.; Sawabe, M.; Okayasu, I.; Fujiwara, M.; Kammori, M.; Mafune, K.; Kato, M.; et al. Correlation of telomere lengths in normal and cancers tissue in the large bowel. Cancer Lett. 2000, 158, 179-184. [CrossRef]

142. Odagiri, E.; Kanada, N.; Jibiki, K.; Demura, R.; Aikawa, E.; Demura, H. Reduction of telomeric length and c-erbB-2 gene amplification in human breast cancer, fibroadenoma, and gynecomastia. Relationship to histologic grade and clinical parameters. Cancer 1994, 73, 2978-2984. [CrossRef]

143. Heaphy, C.M.; Gaonkar, G.; Peskoe, S.B.; Joshu, C.E.; De Marzo, A.M.; Lucia, M.S.; Goodman, P.J.; Lippman, S.M.; Thompson, I.M., Jr.; Platz, E.A.; et al. Prostate stromal cell telomere shortening is associated with risk of prostate cancer in the placebo arm of the Prostate Cancer Prevention Trial. Prostate 2015, 75, 1160-1166. [CrossRef] [PubMed]

144. Valls, C.; Pinol, C.; Rene, J.M.; Buenestado, J.; Vinas, J. Telomere length is a prognostic factor for overall survival in colorectal cancer. Colorectal Dis. 2011, 13, 1265-1272. [CrossRef] [PubMed]

145. Telomeres Mendelian Randomization, C.; Haycock, P.C.; Burgess, S.; Nounu, A.; Zheng, J.; Okoli, G.N.; Bowden, J.; Wade, K.H.; Timpson, N.J.; Evans, D.M.; et al. Association Between Telomere Length and Risk of Cancer and Non-Neoplastic Diseases: A Mendelian Randomization Study. JAMA Oncol. 2017, 3, 636-651. [CrossRef]

146. Willeit, P.; Willeit, J.; Mayr, A.; Weger, S.; Oberhollenzer, F.; Brandstatter, A.; Kronenberg, F.; Kiechl, S. Telomere length and risk of incident cancer and cancer mortality. JAMA 2010, 304, 69-75. [CrossRef]

147. Weischer, M.; Nordestgaard, B.G.; Cawthon, R.M.; Freiberg, J.J.; Tybjaerg-Hansen, A.; Bojesen, S.E. Short telomere length, cancer survival, and cancer risk in 47102 individuals. J. Natl. Cancer Inst. 2013, 105, 459-468. [CrossRef]

148. Julin, B.; Shui, I.; Heaphy, C.M.; Joshu, C.E.; Meeker, A.K.; Giovannucci, E.; De Vivo, I.; Platz, E.A. Circulating leukocyte telomere length and risk of overall and aggressive prostate cancer. Br. J. Cancer 2015, 112, 769-776. [CrossRef]

149. Wentzensen, I.M.; Mirabello, L.; Pfeiffer, R.M.; Savage, S.A. The association of telomere length and cancer: A meta-analysis. Cancer Epidemiol. Prev. Biomarkers 2011, 20, 1238-1250. [CrossRef]

150. Zhang, X.; Zhao, Q.; Zhu, W.; Liu, T.; Xie, S.H.; Zhong, L.X.; Cai, Y.Y.; Li, X.N.; Liang, M.; Chen, W.; et al. The Association of Telomere Length in Peripheral Blood Cells with Cancer Risk: A Systematic Review and Meta-analysis of Prospective Studies. Cancer Epidemiol. Prev. Biomarkers 2017, 26, 1381-1390. [CrossRef]

151. D'Adda di Fagagna, F.; Reaper, P.M.; Clay-Farrace, L.; Fiegler, H.; Carr, P.; Von Zglinicki, T.; Saretzki, G.; Carter, N.P.; Jackson, S.P. A DNA damage checkpoint response in telomere-initiated senescence. Nature 2003, 426, 194-198. [CrossRef] [PubMed]

152. Takai, H.; Smogorzewska, A.; de Lange, T. DNA damage foci at dysfunctional telomeres. Curr. Biol. 2003, 13, $1549-1556$. [CrossRef]

153. Counter, C.M.; Avilion, A.A.; LeFeuvre, C.E.; Stewart, N.G.; Greider, C.W.; Harley, C.B.; Bacchetti, S. Telomere shortening associated with chromosome instability is arrested in immortal cells which express telomerase activity. EMBO J. 1992, 11, 1921-1929. [CrossRef] [PubMed]

154. Harley, C.B.; Kim, N.W.; Prowse, K.R.; Weinrich, S.L.; Hirsch, K.S.; West, M.D.; Bacchetti, S.; Hirte, H.W.; Counter, C.M.; Greider, C.W.; et al. Telomerase, cell immortality, and cancer. Cold Spring Harb. Symp. Quant. Biol. 1994, 59, 307-315. [CrossRef] [PubMed]

155. Kim, N.W.; Piatyszek, M.A.; Prowse, K.R.; Harley, C.B.; West, M.D.; Ho, P.L.; Coviello, G.M.; Wright, W.E.; Weinrich, S.L.; Shay, J.W. Specific association of human telomerase activity with immortal cells and cancer. Science 1994, 266, 2011-2015. [CrossRef]

156. Vinagre, J.; Almeida, A.; Populo, H.; Batista, R.; Lyra, J.; Pinto, V.; Coelho, R.; Celestino, R.; Prazeres, H.; Lima, L.; et al. Frequency of TERT promoter mutations in human cancers. Nat. Commun. 2013, 4, 2185. [CrossRef]

157. Horn, S.; Figl, A.; Rachakonda, P.S.; Fischer, C.; Sucker, A.; Gast, A.; Kadel, S.; Moll, I.; Nagore, E.; Hemminki, K.; et al. TERT promoter mutations in familial and sporadic melanoma. Science 2013, 339, 959-961. [CrossRef] 
158. Killela, P.J.; Reitman, Z.J.; Jiao, Y.; Bettegowda, C.; Agrawal, N.; Diaz, L.A., Jr.; Friedman, A.H.; Friedman, H.; Gallia, G.L.; Giovanella, B.C.; et al. TERT promoter mutations occur frequently in gliomas and a subset of tumors derived from cells with low rates of self-renewal. Proc. Natl. Acad. Sci. USA 2013, 110, 6021-6026. [CrossRef]

159. Kinde, I.; Munari, E.; Faraj, S.F.; Hruban, R.H.; Schoenberg, M.; Bivalacqua, T.; Allaf, M.; Springer, S.; Wang, Y.; Diaz, L.A., Jr.; et al. TERT promoter mutations occur early in urothelial neoplasia and are biomarkers of early disease and disease recurrence in urine. Cancer Res. 2013, 73, 7162-7167. [CrossRef]

160. Stern, J.L.; Theodorescu, D.; Vogelstein, B.; Papadopoulos, N.; Cech, T.R. Mutation of the TERT promoter, switch to active chromatin, and monoallelic TERT expression in multiple cancers. Genes Dev. 2015, 29, 2219-2224. [CrossRef]

161. Bell, R.J.; Rube, H.T.; Kreig, A.; Mancini, A.; Fouse, S.D.; Nagarajan, R.P.; Choi, S.; Hong, C.; He, D.; Pekmezci, M.; et al. Cancer. The transcription factor GABP selectively binds and activates the mutant TERT promoter in cancer. Science 2015, 348, 1036-1039. [CrossRef]

162. Barthel, F.P.; Wei, W.; Tang, M.; Martinez-Ledesma, E.; Hu, X.; Amin, S.B.; Akdemir, K.C.; Seth, S.; Song, X.; Wang, Q.; et al. Systematic analysis of telomere length and somatic alterations in 31 cancer types. Nat. Genet. 2017, 49, 349-357. [CrossRef]

163. Peifer, M.; Hertwig, F.; Roels, F.; Dreidax, D.; Gartlgruber, M.; Menon, R.; Kramer, A.; Roncaioli, J.L.; Sand, F.; Heuckmann, J.M.; et al. Telomerase activation by genomic rearrangements in high-risk neuroblastoma. Nature 2015, 526, 700-704. [CrossRef]

164. Valentijn, L.J.; Koster, J.; Zwijnenburg, D.A.; Hasselt, N.E.; van Sluis, P.; Volckmann, R.; van Noesel, M.M.; George, R.E.; Tytgat, G.A.; Molenaar, J.J.; et al. TERT rearrangements are frequent in neuroblastoma and identify aggressive tumors. Nat. Genet. 2015, 47, 1411-1414. [CrossRef]

165. Kawai-Kitahata, F.; Asahina, Y.; Tanaka, S.; Kakinuma, S.; Murakawa, M.; Nitta, S.; Watanabe, T.; Otani, S.; Taniguchi, M.; Goto, F.; et al. Comprehensive analyses of mutations and hepatitis B virus integration in hepatocellular carcinoma with clinicopathological features. J. Gastroenterol. 2016, 51, 473-486. [CrossRef]

166. Dilley, R.L.; Greenberg, R.A. ALTernative Telomere Maintenance and Cancer. Trends Cancer 2015, 1, 145-156. [CrossRef]

167. Yuan, X.; Larsson, C.; Xu, D. Mechanisms underlying the activation of TERT transcription and telomerase activity in human cancer: Old actors and new players. Oncogene 2019, 38, 6172-6183. [CrossRef]

168. Relitti, N.; Saraswati, A.P.; Federico, S.; Khan, T.; Brindisi, M.; Zisterer, D.; Brogi, S.; Gemma, S.; Butini, S.; Campiani, G. Telomerase-based Cancer Therapeutics: A Review on their Clinical Trials. Curr. Top. Med. Chem. 2020, 20, 433-457. [CrossRef] [PubMed]

169. Ruden, M.; Puri, N. Novel anticancer therapeutics targeting telomerase. Cancer Treat. Rev. 2013, 39, 444-456. [CrossRef] [PubMed]

170. Thomas, P.; NJ, O.C.; Fenech, M. Telomere length in white blood cells, buccal cells and brain tissue and its variation with ageing and Alzheimer's disease. Mech. Ageing Dev. 2008, 129, 183-190. [CrossRef] [PubMed]

171. Panossian, L.A.; Porter, V.R.; Valenzuela, H.F.; Zhu, X.; Reback, E.; Masterman, D.; Cummings, J.L.; Effros, R.B. Telomere shortening in T cells correlates with Alzheimer's disease status. Neurobiol. Aging 2003, 24, 77-84. [CrossRef]

172. Forero, D.A.; Gonzalez-Giraldo, Y.; Lopez-Quintero, C.; Castro-Vega, L.J.; Barreto, G.E.; Perry, G. Meta-analysis of Telomere Length in Alzheimer's Disease. J. Gerontol. A Biol. Sci. Med. Sci. 2016, 71, 1069-1073. [CrossRef] [PubMed]

173. Honig, L.S.; Kang, M.S.; Schupf, N.; Lee, J.H.; Mayeux, R. Association of shorter leukocyte telomere repeat length with dementia and mortality. Arch. Neurol. 2012, 69, 1332-1339. [CrossRef]

174. Fani, L.; Hilal, S.; Sedaghat, S.; Broer, L.; Licher, S.; Arp, P.P.; van Meurs, J.B.J.; Ikram, M.K.; Ikram, M.A. Telomere Length and the Risk of Alzheimer's Disease: The Rotterdam Study. J. Alzheimers Dis. 2020, 73, 707-714. [CrossRef] [PubMed]

175. Spilsbury, A.; Miwa, S.; Attems, J.; Saretzki, G. The role of telomerase protein TERT in Alzheimer's disease and in tau-related pathology in vitro. J. Neurosci. 2015, 35, 1659-1674. [CrossRef]

176. Rivera, T.; Haggblom, C.; Cosconati, S.; Karlseder, J. A balance between elongation and trimming regulates telomere stability in stem cells. Nat. Struct. Mol. Biol. 2017, 24, 30-39. [CrossRef]

177. Tedone, E.; Arosio, B.; Colombo, F.; Ferri, E.; Asselineau, D.; Piette, F.; Gussago, C.; Belmin, J.; Pariel, S.; Benlhassan, K.; et al. Leukocyte Telomere Length in Alzheimer's Disease Patients with a Different Rate of Progression. J. Alzheimers Dis. 2015, 46, 761-769. [CrossRef] [PubMed]

178. Lukens, J.N.; Van Deerlin, V.; Clark, C.M.; Xie, S.X.; Johnson, F.B. Comparisons of telomere lengths in peripheral blood and cerebellum in Alzheimer's disease. Alzheimers Dement. 2009, 5, 463-469. [CrossRef]

179. Fragkiadaki, P.; Nikitovic, D.; Kalliantasi, K.; Sarandi, E.; Thanasoula, M.; Stivaktakis, P.D.; Nepka, C.; Spandidos, D.A.; Tosounidis, T.; Tsatsakis, A. Telomere length and telomerase activity in osteoporosis and osteoarthritis. Exp. Ther. Med. 2020, 19, 1626-1632. [CrossRef]

180. Valdes, A.M.; Richards, J.B.; Gardner, J.P.; Swaminathan, R.; Kimura, M.; Xiaobin, L.; Aviv, A.; Spector, T.D. Telomere length in leukocytes correlates with bone mineral density and is shorter in women with osteoporosis. Osteoporos. Int. 2007, 18, 1203-1210. [CrossRef]

181. Bekaert, S.; Van Pottelbergh, I.; De Meyer, T.; Zmierczak, H.; Kaufman, J.M.; Van Oostveldt, P.; Goemaere, S. Telomere length versus hormonal and bone mineral status in healthy elderly men. Mech. Ageing Dev. 2005, 126, 1115-1122. [CrossRef]

182. Rodriguez, J.P.; Garat, S.; Gajardo, H.; Pino, A.M.; Seitz, G. Abnormal osteogenesis in osteoporotic patients is reflected by altered mesenchymal stem cells dynamics. J. Cell Biochem. 1999, 75, 414-423. [CrossRef] 
183. Saeed, H.; Abdallah, B.M.; Ditzel, N.; Catala-Lehnen, P.; Qiu, W.; Amling, M.; Kassem, M. Telomerase-deficient mice exhibit bone loss owing to defects in osteoblasts and increased osteoclastogenesis by inflammatory microenvironment. J. Bone Miner. Res. 2011, 26, 1494-1505. [CrossRef]

184. Wang, H.; Chen, Q.; Lee, S.H.; Choi, Y.; Johnson, F.B.; Pignolo, R.J. Impairment of osteoblast differentiation due to proliferationindependent telomere dysfunction in mouse models of accelerated aging. Aging Cell 2012, 11, 704-713. [CrossRef]

185. Pignolo, R.J.; Suda, R.K.; McMillan, E.A.; Shen, J.; Lee, S.H.; Choi, Y.; Wright, A.C.; Johnson, F.B. Defects in telomere maintenance molecules impair osteoblast differentiation and promote osteoporosis. Aging Cell 2008, 7, 23-31. [CrossRef]

186. Sanders, J.L.; Cauley, J.A.; Boudreau, R.M.; Zmuda, J.M.; Strotmeyer, E.S.; Opresko, P.L.; Hsueh, W.C.; Cawthon, R.M.; Li, R.; Harris, T.B.; et al. Leukocyte Telomere Length Is Not Associated With BMD, Osteoporosis, or Fracture in Older Adults: Results From the Health, Aging and Body Composition Study. J. Bone Miner. Res. 2009, 24, 1531-1536. [CrossRef] [PubMed]

187. Tang, N.L.; Woo, J.; Suen, E.W.; Liao, C.D.; Leung, J.C.; Leung, P.C. The effect of telomere length, a marker of biological aging, on bone mineral density in elderly population. Osteoporos. Int. 2010, 21, 89-97. [CrossRef] [PubMed]

188. Kveiborg, M.; Kassem, M.; Langdahl, B.; Eriksen, E.F.; Clark, B.F.; Rattan, S.I. Telomere shortening during aging of human osteoblasts in vitro and leukocytes in vivo: Lack of excessive telomere loss in osteoporotic patients. Mech. Ageing Dev. 1999, 106, 261-271. [CrossRef]

189. Lai, T.P.; Wright, W.E.; Shay, J.W. Comparison of telomere length measurement methods. Philos. Trans. R. Soc. Lond. B Biol. Sci. 2018, 373, 20160451. [CrossRef] [PubMed]

190. Baerlocher, G.M.; Vulto, I.; de Jong, G.; Lansdorp, P.M. Flow cytometry and FISH to measure the average length of telomeres (flow FISH). Nat. Protoc. 2006, 1, 2365-2376. [CrossRef] [PubMed]

191. Bendix, L.; Horn, P.B.; Jensen, U.B.; Rubelj, I.; Kolvraa, S. The load of short telomeres, estimated by a new method, Universal STELA, correlates with number of senescent cells. Aging Cell 2010, 9, 383-397. [CrossRef]

192. Cawthon, R.M. Telomere length measurement by a novel monochrome multiplex quantitative PCR method. Nucleic Acids Res. 2009, 37, e21. [CrossRef]

193. Kimura, M.; Aviv, A. Measurement of telomere DNA content by dot blot analysis. Nucleic Acids Res. 2011, 39, e84. [CrossRef]

194. Hemann, M.T.; Strong, M.A.; Hao, L.Y.; Greider, C.W. The shortest telomere, not average telomere length, is critical for cell viability and chromosome stability. Cell 2001, 107, 67-77. [CrossRef]

195. Ludlow, A.T.; Robin, J.D.; Sayed, M.; Litterst, C.M.; Shelton, D.N.; Shay, J.W.; Wright, W.E. Quantitative telomerase enzyme activity determination using droplet digital PCR with single cell resolution. Nucleic Acids Res. 2014, 42, e104. [CrossRef] [PubMed]

196. Ludlow, A.T.; Shelton, D.; Wright, W.E.; Shay, J.W. ddTRAP: A Method for Sensitive and Precise Quantification of Telomerase Activity. Methods Mol. Biol. 2018, 1768, 513-529. [CrossRef] [PubMed]

197. Chen, W.; Kimura, M.; Kim, S.; Cao, X.; Srinivasan, S.R.; Berenson, G.S.; Kark, J.D.; Aviv, A. Longitudinal versus cross-sectional evaluations of leukocyte telomere length dynamics: Age-dependent telomere shortening is the rule. J. Gerontol. A Biol. Sci. Med. Sci. 2011, 66, 312-319. [CrossRef] [PubMed]

198. Dlouha, D.; Maluskova, J.; Kralova Lesna, I.; Lanska, V.; Hubacek, J.A. Comparison of the relative telomere length measured in leukocytes and eleven different human tissues. Physiol. Res. 2014, 63, S343-S350. [CrossRef]

199. Von Zglinicki, T.; Martin-Ruiz, C.M. Telomeres as biomarkers for ageing and age-related diseases. Curr. Mol. Med. 2005, 5, 197-203. [CrossRef] [PubMed]

200. Demanelis, K.; Jasmine, F.; Chen, L.S.; Chernoff, M.; Tong, L.; Delgado, D.; Zhang, C.; Shinkle, J.; Sabarinathan, M.; Lin, H.; et al. Determinants of telomere length across human tissues. Science 2020, 369, eaaz6876. [CrossRef] 